Editorial

\title{
Multilingualism and Social Inclusion
}

\author{
László Marácz ${ }^{1,2, *}$ and Silvia Adamo ${ }^{3}$ \\ ${ }^{1}$ Faculty of Humanities, University of Amsterdam, 1012 CX Amsterdam, The Netherlands; E-Mail: I.k.maracz@uva.nl \\ 2 Department of International Relations, Gumilyov Eurasian National University, 010000 Astana, Kazakhstan \\ ${ }^{3}$ Faculty of Law, University of Copenhagen, 2300 Copenhagen S, Denmark; E-Mail: sia@jur.ku.dk \\ * Corresponding author
}

Submitted: 25 November 2017 | Published: 22 December 2017

\begin{abstract}
This is a thematic issue on the relation between multilingualism and social inclusion. Due to globalization, Europeanization, supranational and transnational regulations linguistic diversity and multilingualism are on the rise. Migration and old and new forms of mobility play an important role in these processes. As a consequence, English as the only global language is spreading around the world, including Europe and the European Union. Social and linguistic inclusion was accounted for in the pre-globalization age by the nation-state ideology implementing the 'one nation-one people-one language' doctrine into practice. This lead to forced linguistic assimilation and the elimination of cultural and linguistic heritage. Now, in the present age of globalization, linguistic diversity at the national state level has been recognized and multilingual states have been developing where all types of languages can be used in governance and daily life protected by a legal framework. This does not mean that there is full equality of languages. This carries over to the fair and just social inclusion of the speakers of these weaker, dominated languages as well. There is always a power question related to multilingualism. The ten case studies in this thematic issue elaborate on the relation between multilingualism and social inclusion. The articles in this issue refer to this topic in connection with different spaces, including the city, the island, and the globe; in connection with different groups, like Roma in the former Soviet-Union and ethnic Albanians in Macedonia; in connection with migration and mobility of Nordic pensioners to the south of Europe, and language education in Scotland; and finally in connection with bilingual education in Austria and Estonia as examples of successful practices including multilingualism under one and the same school roof.
\end{abstract}

\section{Keywords}

communication; education; English; Esperanto; language; minorities; multilingualism; global languages; linguistic spaces; social inclusion

\section{Issue}

This editorial is part of the issue "Multilingualism and Social Inclusion", edited by László Marácz (University of Amsterdam, The Netherlands/Gumilyov Eurasian National University, Kazakhstan) and Silvia Adamo (University of Copenhagen, Denmark).

(C) 2017 by the authors; licensee Cogitatio (Lisbon, Portugal). This article is licensed under a Creative Commons Attribution 4.0 International License (CC BY).

\section{Introduction}

Linguistically diverse or multilingual societies are increasing worldwide. This has mainly to do with processes of globalization and Europeanization. Universal norms and standards in order to protect linguistic and cultural identity are spreading around the globe. In parallel, the traditional nation-state regime cultivating the 'one nation- one people-one language ideology' is weakening, creating room for the celebration of linguistic diversity; and there is a proliferation of federal, multilingual states which recognize more than one official language, i.e., the language of the majority as the official language for communication in governance, the public sphere and education. The European Union (EU) now recognizing 24 official languages is such new federal-type of political con- 
stellation. Further, the proliferation of multilingualism is boosted by all forms of mobility, where mobility is understood as physical migration or new forms of virtual mobility connected to digital networks. Mobility in this sense supports the linguistic and transnational identity of migrants bringing with them new languages that can be called mobile minority languages in reference to traditional minority languages that have a territorial binding in most cases. These migrants speaking unique heritage languages cannot be integrated via linguistic assimilation into the host society. Finally, English is on the rise as a global lingua franca and it is considered that proficiency in English is a prerequisite for a just world. The idea is that more English leads to more social inclusion.

The relation between linguistic diversity and social inclusion is rather complex, however. A good example is the EU. Social and linguistic inclusion is hampered by the fact that although linguistic diversity is generally seen as a positive asset and linguistic rights are on the agenda of policy making in practice we have to do with language hierarchies which imply the exclusion of languages and we hasten to add quite often the social exclusion of their speakers instead of inclusion. Linguistic barriers may also add to the exclusion of non-native speakers in a host state labour market (Adamo, 2018).

Due to the 24 official languages, linguistic diversity in Brussels is hard to manage, however. Hence, the distinction between "official" versus "working" language has become relevant, and this is practically used as a solution for the language issue in the Brussels institutions. The difference between official and working languages is defined in article 6 of the language regulation 1/1958: the institutions are allowed to freely choose their own language regime. The European Commission acknowledges three working languages, namely English, which is used the most, French and German. The latter is used substantially less frequently than the other two. Another example of article 6 is the fact that of the 15 Directorate Generals (DGs) only three use the 24 official languages on their website, including Employment, Social Affairs and Inclusion, Enterprise and Industry, and Justice. All other DGs use a reduced or a monolingual regime consisting of English only.

There are voices to abolish language regulation $1 / 1958$ altogether, due to the fact that an equal treatment of official and working languages is not possible. The main argument is that the democratic language regime of the EU will hamper an efficient functioning of its institutions. Moreover, the reduction of the number of official languages is underpinned by the fact that international English functions practically as a lingua franca in Brussels and European educational recommendations for language teaching favour the learning of English. Hence, monolingualism, i.e., the use of global English is more often practice in the Brussels' institutions. Nevertheless, not only global English will hamper the equality of languages in Brussels it will also render almost impossible the participation of non-speakers of English in the
Europeanisation project. This leads to social exclusion instead of social inclusion.

It is true that traditional minority languages have received more legal recognition in recent decades. European territorial languages are protected by several conventions under the auspice of the Council of Europe that is in close cooperation with the EU. The use of these languages in European national states where the official language of the state is the majority language is guaranteed by international and European legal treaties, like the Framework Convention for the Protection of National Minorities signed on 1 February 1995 in Strasbourg and the European Charter for Regional and Minority Languages adopted on 5 November 1992. Observe that in these cases, there is no full equality between the majority and minority languages leading to linguistic hegemony of the majority language. This situation of inequality is characterized by linguistic asymmetries, subordination, and threshold restrictions for the use of the weaker language. This carries over to the native speakers of these languages. Hence, they might be excluded because they speak a minority language. The traditional territorial languages are still in a better position than mobile minority languages that have received hardly any recognition in the European linguistic space. As Nagy (2015) rightly points out this has to do with power, and officially recognized languages are the languages of power indicating which group is dominating the political arena. Therefore, language policy projects, like 'MIME' that is sponsored by the European Commission FP7-program should find an optimal equilibrium between mobility and social inclusion (Grin, Marácz, Pokorn, \& Kraus, 2014).

This thematic issue will offer ten case studies on the relation between multilingualism and social inclusion, and will reflect on the themes discussed above. The articles address also topics and countries that are far beyond the scope of the EU only. Issues having to do with linguistic diversity and multilingualism play an important role on a global scale. The articles target themes as multilingualism in different spaces, including the city, island and the globe. Esperanto might challenge the only global lingua franca (i.e., English) as a neutral, artificial alternative. The articles also cover language as a source of conflict and an ethno-identity marker of minorities, like Roma in the former Soviet-Union and Albanians in Macedonia; the effects of mobility and migration on multilingual communication in the case of Northern European pensioners in the south of Europe and education in Scotland; and bilingual education in Austria and Estonia as illustrative cases of social inclusion under one and the same but linguistically diverse school roof.

\section{Multilingualism in Different Spaces}

In their article, Yaron Matras and Alex Robertson (2017) focus on the language and social policies employed in a British university setting. Describing the work carried out by the research unit Multilingual Manchester (MLM), 
the authors illustrate how initiatives for awareness of language diversity can sustain a development towards a more inclusive society. The article shows how the activities proposed in a model of participatory research such as MLM can pave the way towards an appreciation of language diversity as a vital element of social inclusion.

Through an examination of the linguistic landscape of Manila during a protest march in November 2016, Jennifer Monje (2017) uses data such as mobile posters, banners, t-shirts, etc., to map the linguistic composition and 'ethnolinguistic vitality' of the city. By analyzing these mobile and unfixed linguistic expressions, the article explores the city of Manila's multilingual nature and at the same time, the strategies that can be used for displaying dissent through linguistic devices.

The article by Herman Bröring and Eric Mijts (2017) explores the language practices in postcolonial small island states, in the specific case study Aruba, and their relation of dependency on former colonizer states' language regime. The starting point of the analysis focuses on the limited protection offered by international treaties to creole languages spoken by the majority of the inhabitants of the former colonial island. From there the authors proceed to analyse how the influence of Dutch language in governance, judiciary, and education currently affects the Aruba legislation. In this view, the language planning and policy employed in Aruba does not support a 'linguistically inclusive society' where the island's population can be represented.

Federico Gobbo's (2017) contribution describes and contextualizes the creation and development of Esperanto. Acclaimed as a true example of lingua franca, the evolution of Esperanto is nuanced in Gobbo's exposition by exposing the commitment of Esperanto activists to particular sets of beliefs and 'programs for changing the world'. By presenting and discussing the history and narratives of Esperanto, the author also proposes a renewed assessment of the predominant position of English as the current lingua franca of the world.

\section{Multilingualism and Minorities}

The article by Elena Marushiakova and Vesselin Popov (2017) introduces us to the developments in the politics of multilingualism and educational policies for Roma children in the Soviet Union. Formerly known as 'gypsy schools', these institutions provided instruction in their Romani mother tongue, and thanks also to specially trained Roma teachers, high levels of literacy were achieved in the Roma communities. After the closing of these special schools in 1938, the authors describe a lack of multilingual awareness in the subsequent move to include Roma children into mainstream schools. Individual elements of multilingualism and educational policies specifically targeting Roma children have been reintroduced only in a few countries after the collapse of the communist regimes in Eastern Europe. The article also mentions the lack of interest of Roma people in accept- ing a mother tongue based multilingual education, in rebuttal of the positive results of Roma education in the Soviet Union.

The article by Renata Treneska-Deskoska (2017) sets the frame around the question of why and how states ought to accomodate linguistic diversity. The author presents the context of Macedonia, with its ethnolinguistic communities that have challenged the state's organisation since its 1991 independence. Adopting a 'promotional approach', Macedonia has granted linguistic rights to minorities also by means of constitutional change, which introduced Albanian as an official language alongside Macedonian. The article examines the complex relationship between language policies and 'ethnic mistrust' and the potential and limits of legislation in accomodating the tensions among the two.

\section{Multilingualism and Migration}

In their contribution, Per Gustafson and Ann Elisabeth Laksfoss Cardozo (2017) analyze the multilingual context in which international retirees live, in their 'search for a better quality of life'. Taking as a case study Scandinavian (Norwegian and Swedish) retirees residing in the province of Alicante, Spain, the authors confront issues of social, cultural, and linguistic inclusion that are present in modern international retirement by focusing especially on the issue of language. After exploring the particular linguistic landscape of Alicante and the retirees' linguistic practices, the authors discuss how this particular kind of migration movement affects the conditions for social inclusion, as well as our understanding of the very concept.

In the article by Róisín McKelvey (2017), we have the opportunity to explore a relatively unknown context of multilingualism found in the educational system of Scotland. The increased linguistic diversity of the country, as in the wider UK context, has spurred a demand for language policies and multilingual public services. From this starting point, the article evaluates the legal instruments and policies promoting language learning and multilingualism, considering also the challenges to their implementation in an optic of inclusion. The conclusions highlight the tension between goals of inclusion and the increased mobility and multilingual demographics in Scotland.

\section{Minority Languages}

The article by Ulrike Jessner and Kerstin Mayr-Keiler (2017) examines the context of language choice and language use in children attending bilingual and multilingual schools in Austria. By means of a sociolinguistic analysis and employing empirical data, the article explores how children utilise socio-contextual information in order to inform their language choice and language use. The analysis concludes by evaluating how these dynamics of language practice interplay with broader considerations on social inclusion. 
Finally, the linguistic landscape in Estonia is at the center of the article by Svetlana L'nyavskiy-Ekelund and Maarja Siiner (2017), who analyze the system of parallel and separated schools for Russian and Estonian speaking children. Contested as a system contributing to social injustice and segregation, the example of two private schools and their linguistic practices is examined, as the schools aim to drive inclusive institutions by employing inter alia multilingual practices. The case studies can then be used to question how a positive attitude to multilingual competences could further improve social cohesion in Estonia if the same outlook was broadened to a larger set of schools.

\section{Acknowledgements}

The research leading to these results has received funding from the EU's Seventh Framework Programme (FP7/2007-2013) under grant agreement no. 613344.

\section{Conflict of Interests}

The authors declare no conflict of interests.

\section{References}

Adamo, S. (2018). What comes first, language or work? Linguistic barriers for accessing the labour market. In E. Ioratti, G. Di Paolo, E. Pulice (Eds.), Legal and factual barriers to the exercise of EU citizens economic rights. Cheltenham: Edward Elgar.

Bröring, H., \& Mijts, E. (2017). Language planning and policy, law and (post)colonial relations in small island states: A case study. Social Inclusion, 5(4), 29-37.

Gobbo, F. (2017). Beyond the nation-state? The ideology of the Esperanto movement between neutralism and multilingualism. Social Inclusion, 5(4), 38-47.

Grin, F., Marácz, L., Pokorn, N. K., \& Kraus, P. A. (2014). Mobility and inclusion in multilingual Europe: $A$ position paper on the MIME Project. Retrieved from www.mime-project.org/resources/MIME-POSITIONPAPER-V4.pdf

Gustafson, P., \& Laksfoss Cardozo, A. E. (2017). Language use and social inclusion in international retirement migration. Social Inclusion, 5(4), 69-77.

Jessner, U., \& Mayr-Keiler, K. (2017). Why context matters: Social inclusion and multilingualism in an Austrian school setting. Social Inclusion, 5(4), 87-97.

L'nyavskiy-Ekelund, S., \& Siiner, M. (2017). Fostering social inclusion through multilingual habitus in Estonia: A case study of the Open School of Kalamaja and the Sakala Private School. Social Inclusion, 5(4), 98-107.

Marushiakova, E., \& Popov, V. (2017). Politics of multilingualism in Roma education in early Soviet Union and its current projections. Social Inclusion, 5(4), 48-59.

Matras, Y., \& Robertson, A. (2017). Urban multilingualism and the civic university: A dynamic, non-linear model of participatory research. Social Inclusion, 5(4), 5-13.

McKelvey, R. (2017). Language provision in education: A view from Scotland. Social Inclusion, 5(4), 78-86.

Monje, J. (2017). "Hindi bayani/Not a hero": The linguistic landscape of protest in Manila. Social Inclusion, 5(4), 14-28.

Nagy, N. (2015). A hatalom nyelve-A nyelv hatalma: nyelvi jog és nyelvpolitika Európa történetében (The language of power-The power of language: language legislation and language policy in the history of Europe). PhD dissertation, University of Pécs.

Treneska-Deskoska, R. (2017). Accommodating multilingualism in Macedonia. Social Inclusion, 5(4), 60-68.

\section{About the Authors}

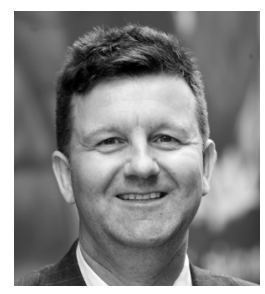

László Marácz defended his PhD dissertation in General Linguistics at the University of Groningen in 1989. Since 1992, he is affiliated as an Assistant Professor to the Department of European Studies of the University of Amsterdam. Prof. Dr. Marácz is 'Honorary Professor' of the L.N. Gumilyov Eurasian National University in Astana, Kazakhstan. He is vice-coordinator of the MIME-consortium (www.projectmime.org) that won the European FP7-tender in 2013 under the reference of 'SSH Call 2013.5.2-1: Multilingual Challenge for the European Citizen'.

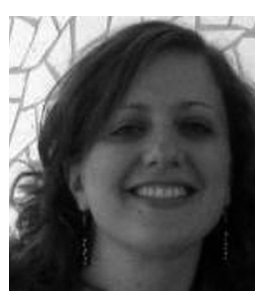

Silvia Adamo is Associate Professor at the Faculty of Law, University of Copenhagen. Her research interests and publications focus on migration and integration law, EU law, citizenship law and theory, critical legal theory, and linguistic diversity. She was a member of the international collaborative research project 'bEUcitizen: Barriers towards European Citizenship', funded by the EU's Seventh Framework Programme (2014-2016). She is the co-editor of the book Linguistic Diversity and European Democracy (Ashgate, 2011) and the Editor-in-Chief of Retfærd, Nordic Journal of Law and Justice. 